\title{
Nano-Immobilized Biocatalysts for Biodiesel Production from Renewable and Sustainable Resources
}

\author{
Keon Hee Kim, Ok Kyung Lee and Eun Yeol Lee* \\ Department of Chemical Engineering, Kyung Hee University, Gyeonggi-do 17104, Korea; \\ waveskgh@naver.com (K.H.K.); okblessyou@khu.ac.kr (O.K.L.) \\ * Correspondence: eunylee@khu.ac.kr; Tel.: +82-31-201-3839
}

Received: 31 December 2017; Accepted: 3 February 2018; Published: 8 February 2018

\begin{abstract}
The cost of biodiesel production relies on feedstock cost. Edible oil is unfavorable as a biodiesel feedstock because of its expensive price. Thus, non-edible crop oil, waste oil, and microalgae oil have been considered as alternative resources. Non-edible crop oil and waste cooking oil are more suitable for enzymatic transesterification because they include a large amount of free fatty acids. Recently, enzymes have been integrated with nanomaterials as immobilization carriers. Nanomaterials can increase biocatalytic efficiency. The development of a nano-immobilized enzyme is one of the key factors for cost-effective biodiesel production. This paper presents the technology development of nanomaterials, including nanoparticles (magnetic and non-magnetic), carbon nanotubes, and nanofibers, and their application to the nano-immobilization of biocatalysts. The current status of biodiesel production using a variety of nano-immobilized lipase is also discussed.
\end{abstract}

Keywords: nanomaterials; nano-immobilized enzyme; immobilization; biodiesel; lipase

\section{Introduction}

Demand for energy has risen continuously [1], and the world's oil reserves can be depleted by 2050 with the current consumption rate [2]. This causes the price volatility of petroleum-based fuels, and has stimulated research on the renewable and sustainable production of biofuels. Biomass can be a promising feedstock to meet current and future demand for renewable and sustainable fuel. Biofuels generated from biomass include biodiesel, bioethanol, biohydrogen, and biomethane. Bioethanol is produced based on a three-step process: pre-treatment, saccharification, and fermentation. Bioethanol has been produced using sugarcane, corn, wheat, and potatoes, which has resulted in an increase in world grain prices. In order to avoid the moral issue of using food for fuel production, lignocelluloses biomass is being considered as the feedstock for the production of bioethanol. Biodiesel is produced by transesterification to convert long-chain triglycerides into fatty acid methyl esters (FAMEs). Biodiesel is an attractive alternative fuel because it is nontoxic, renewable, and biodegradable. Its combustion emission profile is favorable because of the low emissions of $\mathrm{CO}, \mathrm{NO}_{\mathrm{x}}$, sulfur content, and particulate matter [3]. The benefits of biofuels over traditional fuels are greater energy security and reduced socioeconomic issues of environmental pollution [4]. Biodiesel is expected to minimize the greenhouse effect [5]. Furthermore, compared to petro-diesel, biodiesel has shown a higher combustion efficiency, flash point, and cetane number, and better lubricant efficiency.

The renewable feedstock for biodiesel production is divided into three types: edible oil, non-edible oil, and waste edible oil. Edible oil, such as vegetable oil, as the raw material is unfavorable for biodiesel production because of its high cost and the issue of using food for fuel production [6]. Recently, alternative biofuel resources, such as non-edible oil, waste oil, and microalgae oil have been explored to address the issues of the edible oil-derived biodiesel production. Jatropha, karanja, mahua, 
polanga, rubber, and castor oil are non-edible oils for biodiesel production and are cheaper than edible oils [7]. Waste oil, such as waste cooking oil, grease, and soap stock, is an abundant feedstock with low cost. The total amount of waste cooking oil is 16.6 million tons per year [8]. Microalgae is a non-edible crop that can produce 25 times more oil than plants. Some microalgae can accumulate oil up to $50 \%$ by weight of dry biomass [9]. Microalgae is an environmentally friendly biomass due to its high capacity for carbon dioxide fixation, and it has a higher growth rate than terrestrial plants $[9,10]$.

Transesterification reactions of oils require short-chain alcohols as an acyl acceptor in the presence of catalysts, such as acid/base chemocatalysts or enzymes. Non-edible oil and waste cooking oil are problematic in the conventional biodiesel production process using alkaline catalysts because they have a high content of free fatty acid (FFA) [11]. A feedstock with high FFA content can be used in the lipase-catalyzed process [12]. The lipase-catalyzed process has environmental and economic advantages, such as a lower energy consumption requirement, a low post-treatment cost, and a broader feedstock specificity than the chemical catalytic process $[13,14]$.

One drawback of the lipase process is the high cost of the enzyme. Thus, the use of immobilized lipase is important to reduce production cost [14]. In addition, the immobilized lipase is easier to handle than free lipase, and in some cases, it shows improved performance in terms of $\mathrm{pH}$ tolerance, substrate selectivity, thermal stability, and functional stability $[15,16]$.

In general, enzymes are immobilized on macro/micro materials for various applications, including use in biosensors, biofuel production, and drug delivery [15]. The immobilized enzymes on macro/micro materials have some technical issues, such as distortion of protein configuration, steric hindrance, and a low diffusion rate [17]. To address these issues, many researchers have used nanomaterials as an enzyme support. Nanomaterials as enzyme immobilization agents have many advantages. The large surface-area-to-volume ratios of nanomaterials is one of the main advantages, which allows high enzyme loading and increases mass transfer [18]. In aqueous suspensions, enzyme-bound nanomaterials exhibit Brownian motion, which is different from free enzymes and endow higher enzyme activity than free enzymes $[16,19]$. In this paper, we review and discuss the advances in enzyme immobilization techniques (Section 2), lipase immobilization using nanostructured materials (Section 3), and biodiesel production using nano-immobilized lipase (Section 4).

\section{Enzyme Immobilization Techniques}

\subsection{Cross-Linking Immobilization}

The cross-linking immobilization process attaches the enzymes to one another using a multifunctional reagent [16]. This method does not require a support matrix and the resulting enzyme maintains $100 \%$ activity [20]. However, a loss of enzyme activity via conformational change can occur during immobilization. The control of the cross-linking reaction is difficult; thus, it is not easy to obtain an enzyme with high activity retention [16]. Sheldon et al. [20] developed a cross-linked enzyme aggregates (CLEAs) method for an effective enzyme immobilization. The CLEAs method is very simple and involves enzyme precipitation from aqueous solutions by the addition of non-ionic polymers, salts, or organic solvents. The lipases from Thermomyces lanuginosus and Rhizomucor miehei were precipitated with ammonium sulfate in the presence of SDS as surfactant followed by enzyme crosslinking with glutaraldehyde [21]. The hydrolytic activities of the CLEAs and the lipases were enhanced threefold and twofold, respectively, over those of free enzymes.

\subsection{Adsorption Immobilization}

The adsorption of enzyme on the surface of a support is an old technology and a simple method. It is based on a physical binding mechanism, such as a dipole-dipole, hydrophobic, or van der Waals interaction or hydrogen bonding [18,22]. Physical binding was performed in relatively ambient conditions and showed a high enzyme loading [16,22]. Adsorption immobilization does not provide a high stability and might cause a loss of enzyme molecules during operation and washing 
because of weak binding between the enzyme and the supports [23]. Tang et al. [23] immobilized glucose oxidase (GOD) on a platinum nanoparticle-modified carbon nanotube (CNT) electrode via adsorption. To avoid a loss of GOD, the surface of the GOD/Pt/CNT electrode was coated by Nafion. The Nafion/GOD/Pt/CNT electrodes showed good characteristics: a short response time $(\sim 5 \mathrm{~s})$, a large current density $\left(1.176 \mathrm{~mA} / \mathrm{cm}^{2}\right)$, a large determination range $(0.1-13.5 \mathrm{mM})$, and high sensitivity $\left(91 \mathrm{~mA} / \mathrm{M} \cdot \mathrm{cm}^{2}\right)$. After 22 days, the stability of immobilized GOD on the Nafion-coated $\mathrm{Pt} / \mathrm{CNT}$ electrodes still maintained a $73.5 \%$ value based on an intial response. To overcome the enzyme leaching, the enzyme was immobilized into the pores of polyanilin nanofibers (PANFs) through a three-step process, which included enzyme adsorption, precipitation, and cross-linking (EAPC) [24,25]. Kim et al. [24] have compared GOD activity and the stability of enzyme adsorption (EA), enzyme adsorption and cross-linking (EAC), and EAPC. The relative activities of EA, EAC, and EAPC were $11 \%, 24 \%$, and $100 \%$, respectively, and EAPC showed the highest thermal stability at $50{ }^{\circ} \mathrm{C}$. The high stability of EAPC can be explained by the increase in enzyme loading and the prevention of enzyme leaching and denaturation.

\subsection{Covalent Immobilization}

The covalent immobilization of the biocatalyst is the attachment of enzyme to the nanomatrix by covalent bonding between the enzyme and the supports [16]. The strong binding of enzyme to the support matrix via the covalent bond prevents enzyme leaching from the surface and improves the thermal stability in some cases $[18,22]$. This technique, however, often provokes the deactivation of enzyme because of the conformational restriction of the enzyme by covalent binding [22,26]. Hong et al. [26] immobilized $\alpha$-chymotrypsin on an amine-functionalized superparamagnetic nanogel by covalent binding and compared the stability of the immobilized enzyme and free enzyme. The optimal $\mathrm{pH}$ value of the free enzyme and the immobilized enzyme was at $\mathrm{pH} 7.8$, and the $\mathrm{pH}$ profile was similar. With respect to thermal stability, the free enzyme had no activity above $75^{\circ} \mathrm{C}$, but the residual activity of the immobilized enzyme retained $88.7 \%$ until $85^{\circ} \mathrm{C}$. The storage stability of the free enzyme dramatically decreased down to almost zero after 22 days at $25^{\circ} \mathrm{C}$. In contrast, the activity of the immobilized enzyme decreased only $10 \%$ of its initial activity during 35 days at $25{ }^{\circ} \mathrm{C}$. Kinetic parameters $\left(K_{m}\right.$ and $\left.V_{\max }\right)$ for native and immobilized enzymes were also determined. The $K_{m}$ value of the immobilized enzyme was 1.57 times higher than that of the native enzyme, whereas the $V_{\max }$ value of the immobilized enzyme was smaller than that of the native enzyme. This indicates that the substrate affinity of the immobilized enzyme decreased in comparison with the native enzyme, which might be related to a steric effect and diffusion limitation due to immobilization onto the supports. Kim et al. [27] developed an enzyme aggregate coating method on nanofibers. In the first step, $\alpha$-chymotrypsin (CT) molecules were attached onto the surface of nanofibers via covalent binding. Then, additional enzyme molecules were cross-linked to the attached enzyme molecules via glutaraldehyde treatment, which forms the enzyme aggregate coating. The initial activity of the enzyme aggregate increased nine times compared to the case of only a covalent immobilization enzyme, because the enzyme coating consisted of multiple layers of enzymes on the nanofibers. With respect to enzyme stability, a CT-aggregate-nanofiber was still stable without loss of its activity during a month. This technology can be applied to various nanomaterials and has potential applications in bioconversion, bioremediation, and biosensors [27-29].

\subsection{Entrapment Immobilization}

The entrapment technology entraps the enzyme in a porous gel or fibers $[16,18]$. From a TEM analysis, the diameter of entrapped magnetite crystallites was approximately $20 \mathrm{~nm}$. The entrapment process can protect enzyme activity because of the indirect contact with the confined environment, which minimizes the effects of gas bubbles, mechanical sheer, and hydrophobic solvents [18]. Entrapment immobilizations using nanoparticles are generally based on the reverse-micelle or sol-gel technique [30-34]. Reetz et al. [32] reported the simultaneous entrapment of a lipase Amano PS (from 
Pseudomonas cepacia) and nanostructured magnetite $\left(\mathrm{Fe}_{3} \mathrm{O}_{4}\right)$ containing hydrophobic sol-gel material. The colloidal magnetite-containing lipase was characterized by enzyme activity and was 2-3 times higher than that of free enzyme. Yang et al. [33] reported the simultaneous entrapment of horseradish peroxidase (HPR) and spherical silica-coated nanomagnetite. This technique consisted of two procedures performed in two steps: reverse-micelle and sol-gel processes. Entrapment immobilization by reverse-micelle microemulsion can generate uniform-size nanoparticles, which leads to a strong monodispersion of nanoparticles. Compared to free HPR, the nanoentrapment-immobilized HPR exhibited high stability toward temperature and $\mathrm{pH}$ changes. However, this method required a rigorous optimization process because it was difficult to control the reverse-micelle size [30]. Additionally, the sol-gel process involved harsh reaction conditions for the entrapment immobilization [35]. The new entrapment technology for enzymes and nanoparticles using biomagnetic silica was performed under mild conditions with an improvement in enzyme stability, immobilization efficiency, and loading density $[35,36]$.

The single-enzyme nanoparticles (SENs) method was developed by Kim and Grate in 2003 [37]. Each enzyme molecule was surrounded by a porous composite organic/inorganic network with a thickness of a few nanometers. The SENs method involves a two-step procedure: first, vinyl polymers were grafted onto the enzyme surface by radical polymerization; then, the polymer network around the enzyme surface was formed by silanol condensation. During the vinyl polymerization, the thickness of the polymer network could be controlled. The catalytic efficiency of SENs-CT based on a $K_{\text {cat }} / K_{m}$ $\left(3.44 \times 10^{5} \mathrm{M}^{-1} \mathrm{~s}^{-1}\right)$ value decreased to half that of free enzyme. However, the $K_{m}$ value of SENs-CT was similar to that of free enzyme. This indicates that the SENs had no mass-transfer limitation for the substrate. Yan et al. [38] reported a simple development of nanogels containing a single enzyme. The SENs of HPR showed similar Michaelis-Menten parameters $\left(K_{m}\right.$ and $\left.K_{\text {cat }}\right)$, but the thermal stability of the SENs was enhanced up to $65^{\circ} \mathrm{C}$. Moreover, the enzyme activity was maintained in the presence of polar organic solvents, such as methanol, tetrahydrofuram, and dioxane. The enzyme immobilization techniques are summarized in Figure 1 [18,22].

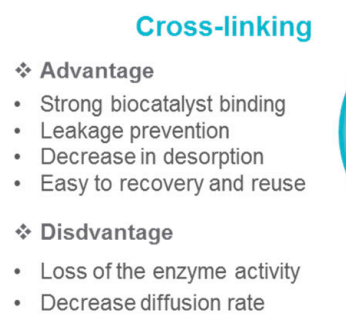

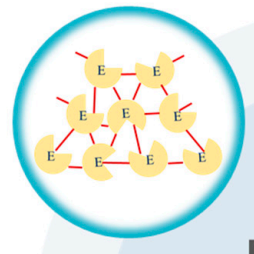

$$
\begin{gathered}
\text { Enzyme } \\
\text { immobilization } \\
\text { methods }
\end{gathered}
$$

Adsorption

* Advantage

- Simple and cheap

- No need to use reagents

- High catalytic acticity

* Disdvantage

- Low stability

- Weak binding on supports
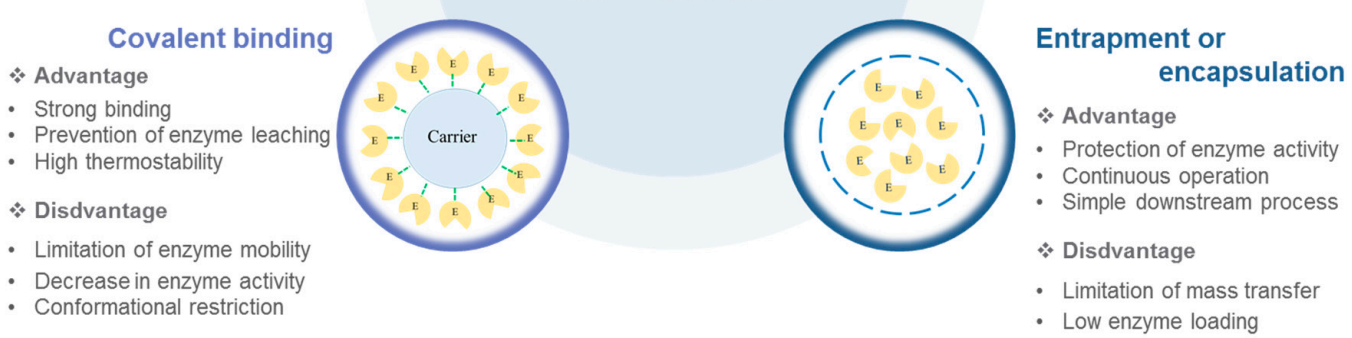

Figure 1. Comparison of different enzyme immobilization techniques (modified from the references of $[18,22])$.

\section{Development of Nano-Immobilized Lipase Biocatalyst}

Lipases have been obtained from fungi, bacteria, animals, and plants [39]. They catalyze the hydrolysis of triglycerides to glycerol and free fatty acids at the oil-water interface. In addition to hydrolytic catalysis, lipases catalyze synthetic reactions, such as esterification and transesterification [40]. Lipases 
have been used as catalysts in the cosmetics, chemical synthesis, detergent formulation, food, and pharmaceuticals industries and in biodiesel production [40,41]. In lipase-catalyzed biodiesel production, the major issue is the high enzyme cost. Thus, the use of immobilized lipases is important for operational cost reduction by the increasing of enzyme reusability. Additionally, in some cases, immobilized lipases have shown higher enzyme activity than free lipases [41]. Recently, many researchers are using nanomaterials as a carrier for enzymes. Nanomaterials have many advantages as an enzyme carrier. The large surface-area-to-volume ratio of nanomaterials allows for high enzyme loading and enhanced mass transfer [18]. In an aqueous suspension, enzyme-bound nanomaterials exhibit Brownian motion, which exhibits higher enzymatic activity than the free enzyme. The illustration of enzyme immobilization to nanomaterials is presented in Figure 2.

(A)
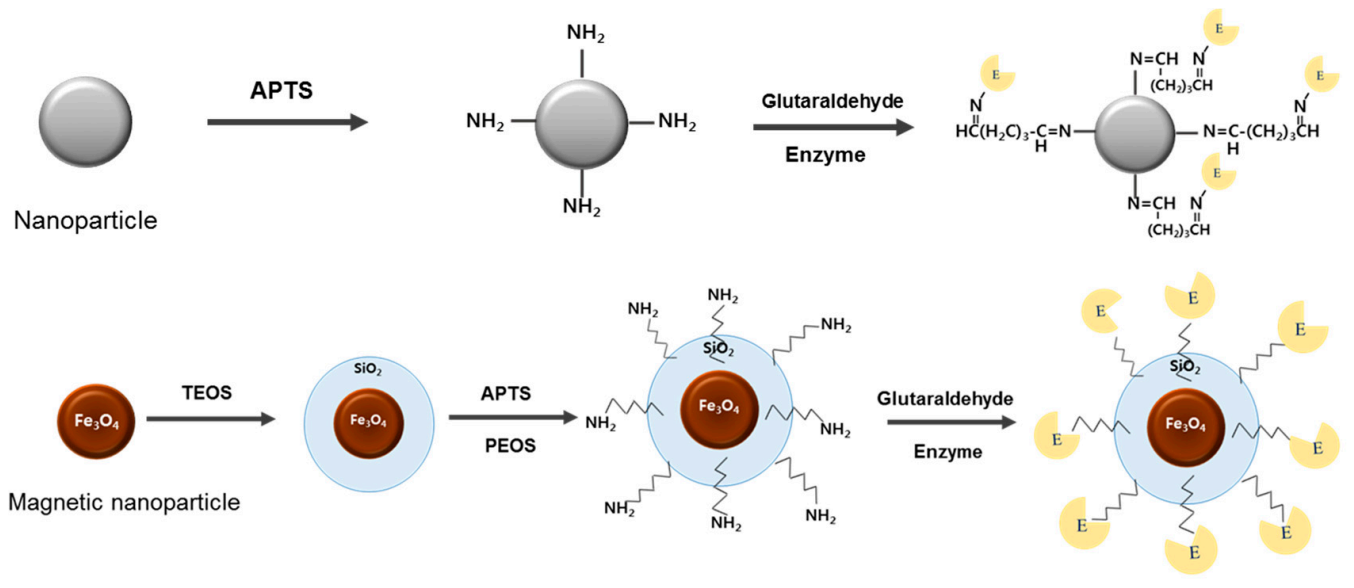

(B)
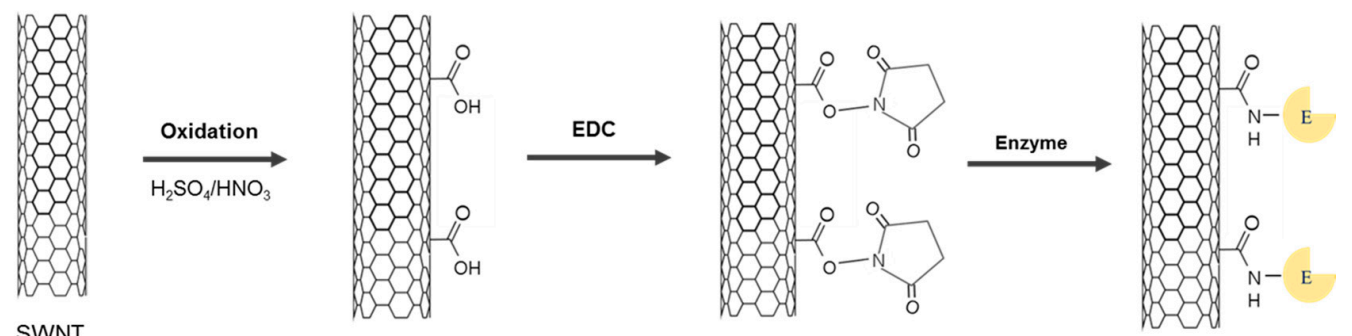

SWNT

(C)

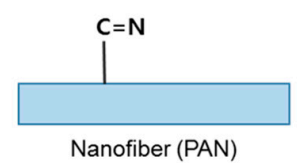

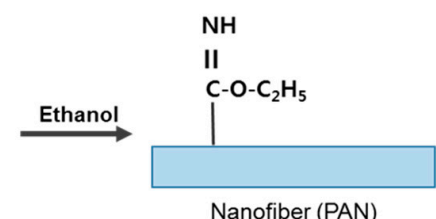

Nanofiber (PAN)

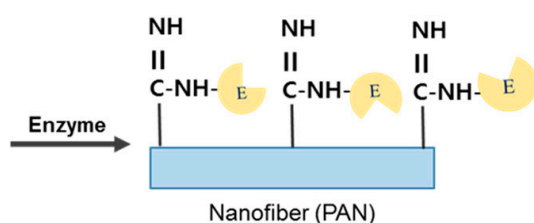

Nanofiber (PAN)

Figure 2. Illustration of enzyme immobilization techniques to nanoparticles (A) (modified from the references of [25,42], nanotubes (B) (modified from the references of [43]), and nanofibers (C) (modified from the references of [44]). APTS: 3-aminopropyltriethoxysilane, TEOS: tetra-ethoxy silane, PEOS: poly-ethoxy silane, PAN: polyacrylonitrile, EDC: $N$-(3-dimethylaminopropyl)- $N^{\prime}-$ ethylcarbodiimide hydrochloride.

\subsection{Nanoparticles-Based Lipase Immobilization}

\subsubsection{Non-Magnetic Nanoparticles}

Nanoparticles with a 1-100 $\mathrm{nm}$ nanoscale diameter have been used for biological applications [45]. Nanoparticle-based carriers have increased the catalytic efficiencies of various lipases, including enhanced activity, stability, and reusability due to their unique size and physical properties $[12,46]$. 
Among nanoparticles, the non-magnetic nanoparticle-attached enzyme is well dispersed in the reaction solution. Thus, regeneration for reuse is often a difficult task and requires high-speed centrifugation for a long time. Non-magnetic nanoparticle carriers include zirconia, silica, polystyrene, chitosan, and polylactic acid (Table 1) [39,47-51]. When immobilized on a hydrophilic inorganic surface, lipases have poor binding ability because a polypeptide chain "lid" of lipases secludes the catalytic site [52]. Chen et al. [47] immobilized Pseudomonas cepacia lipase (PCL) on zirconia nanoparticles grafted with various carboxylic acids (valeric acid, capry acid, stearic acid, oleic acid, linoleic acid, and 1,10-decanedicarboxylic acid). The stearic acid as carboxylic acid surfactant exhibited better activity and enantioselectivity. The initial activity of PCL-stearic- $\mathrm{ZrO}_{2}$ was 10.5 and 16.6 times higher than the unmodified $\mathrm{ZrO}_{2}-\mathrm{PCL}$ and crude lipase powder, respectively. The long hydrophobic chain induced an interfacial activation effect because of the interaction between the polypeptide chain of the lipases and stearic acid. Kim et al. [48] studied the immobilization of Mucor janaicus lipase (MJL) using covalent attachment to ehtylene diamine (EDA)-activated silica nanoparticles. The silica nanoparticles were activated using a coupling agent (glutaraldehyde (GA) or 1,4-phenylene diisothicyanate (NCS)). Using GA or NCS as a coupling agent can avoid side binding between large enzyme molecules and the carrier. Thus, the EDA-GA- and EDA-NCS-activated nanoparticles could access surface areas for enzyme immobilization. The immobilized MJL-attached EDA-GA and EDA-NCS silica nanoparticles enhanced the enzyme loading and activity. The immobilized MJL had a wide range of $\mathrm{pH}$ tolerance and high thermal stability [48]. The relative activity of the lipase immobilized on the EDA-GA and EDA-NCS silica carriers was $115 \%$ and $107 \%$ compared to free enzyme, respectively.

Table 1. List of various immobilized lipases on different nanomaterials. SWNT: single-walled carbon nanotube; MWNT: multi-walled carbon nanotube.

\begin{tabular}{|c|c|c|c|c|c|}
\hline Nanomaterials & Strain & Carrier & $\begin{array}{l}\text { Type of } \\
\text { Binding }\end{array}$ & Special Feature & Refs. \\
\hline \multirow{7}{*}{ Nanoparticles } & Pseudomonas cepacia & Zironia & Covalent & $\begin{array}{l}\text { Increased activity and } \\
\text { enantioselectivity }\end{array}$ & [47] \\
\hline & Mucor japonicus & Silica & Covalent & $\begin{array}{c}\text { Enhanced enzyme loading and } \\
\text { enzyme stability }\end{array}$ & [48] \\
\hline & Candida antarctica & Polystyrene & Adsortion & High hydrolytic activity & [49] \\
\hline & Candida rugosa & Chitosan & Covalent & $\begin{array}{l}\text { High enzyme loading and activity } \\
\text { retention }\end{array}$ & [50] \\
\hline & Candida rugosa & Polylactic acid & Adsorption & Enhanced activity and stability & [51] \\
\hline & Candida rugosa & $\gamma-\mathrm{Fe}_{2} \mathrm{O}_{3}$ & Covalent & Enhanced stability & [53] \\
\hline & Porcine pancreas & Magnetic & Adsorption & Good reusability & [54] \\
\hline \multirow{6}{*}{ Carbon nanotube } & Pseudomonas cepacia & SWNT & $\begin{array}{c}\text { Adsorption, } \\
\text { covalent }\end{array}$ & $\begin{array}{l}\text { Increased retention of enzyme } \\
\text { activity }\end{array}$ & [55] \\
\hline & Rhizopus arrhizus & MWNT & Covalent & Enhanced resolution efficiency & [43] \\
\hline & $\begin{array}{c}\text { Candida rugosa, } \\
\text { C. antarctica B, } \\
\text { Thermomyces lanuginosus }\end{array}$ & MWNT & Adsorption & Enhanced stability & [56] \\
\hline & Candida rugosa & MWNT & Adsorption & High enzyme activity & [57] \\
\hline & Candida rugosa & MWNT & Adsorption & $\begin{array}{l}\text { Enhanced activity and thermal } \\
\text { stability }\end{array}$ & [58] \\
\hline & Candida antarctica & MWNT & Adsorption & Enhanced activity and stability & [59] \\
\hline \multirow{5}{*}{ Nanofibers } & Candida antarctica & Polyacrylnitrate & Covalent & High enzyme stability & [44] \\
\hline & Candida rugosa & $\begin{array}{l}\text { Poly-(acrylonitrile- } \\
\text { comaleic acid) }\end{array}$ & Covalent & High activity and enzyme loading & [60] \\
\hline & Candida rugosa & Cellulose acetate & Covalent & Enhanced thermal stability & [61] \\
\hline & Burkholderia cepacia & Polycaprolactane & Covalent & $\begin{array}{l}\text { Enhanced catalytic activity and } \\
\text { reusability }\end{array}$ & [62] \\
\hline & Candida rugosa & $\begin{array}{l}\text { Polyvinyl alcohol } \\
\text { (PVA) }\end{array}$ & Covalent & $\begin{array}{l}\text { Equivalent esterification activity } \\
\text { to that of Novozyme } 435\end{array}$ & [63] \\
\hline
\end{tabular}


Candida antarctica lipase B (CAL-B) was immobilized on polystyrene nanoparticles via adsorption [49]. Polystyrene nanoparticles were synthesized using a nanoprecipitation technique. Since the enzymes were adsorbed by hydrophobic interactions, the immobilization efficiency was not affected by the change in $\mathrm{pH}$. Nevertheless, the activity of immobilized CAL-B depended on the change in $\mathrm{pH}$. The ionization state of the lipase's active site can be affected by $\mathrm{pH}$ changes. Therefore, the adsorption immobilization of lipases was performed at $\mathrm{pH} 6.0$ to avoid the possibility of enzyme conformation change. The hydrolytic activity of the immobilized lipase on polystyrene nanoparticles was compared with Novozyme 435 and crude enzyme powder, and its activity was 1.16-fold higher than Novozyme 435 and 1.81-fold higher than free enzyme.

\subsubsection{Magnetic Nanoparticles}

The reuse of immobilized enzymes on non-magnetic nanoparticles requires high-speed centrifugation [52]. To overcome these issues, many researchers have studied enzyme immobilization using magnetic nanoparticles, because magnetic nanoparticles can be readily separated the reaction solutions using magnetic attraction $[42,52,53,64-68]$. Nanoscale magnetic particles have a unique property of superparamagnetism [69,70]. They do not form agglomerates at room temperature; thus, they are well-suspended in reaction solution [70]. The magnetic iron oxides have been mostly used as magnetic nanoparticles because of their low toxicity and biocompatibility [69]. Dyal et al. [53] evaluated the activity and stability of Candida rugosa lipase (CRL) attached on $\gamma$ - $\mathrm{Fe}_{2} \mathrm{O}_{3}$ magnetic nanoparticles by covalent binding. The $\gamma-\mathrm{Fe}_{2} \mathrm{O}_{3}$ magnetic nanoparticles were activated with either acetyl or amine groups to connect with the amine groups of lipases. The operational stability of immobilized CRL was significantly improved. Lee et al. [54] developed hydrophobic magnetic nanoparticles to immobilize crude porcine pancreas lipase (PPL). The lipases showed high activation when they were immobilized on the hydrophobic surface of nanoparticles [46,47]. Sodium dodecyl sulfate (SDS) was used as the ligand for hydrophobic $\mathrm{Fe}_{3} \mathrm{O}_{4}$ magnetic nanoparticles. The PPL immobilized on surface-modified magnetic nanoparticles (8-12 nm in size) enhanced the thermal stability compared to free PPL. Both the free and immobilized PPL showed maximum activity at temperatures between 37 and $40^{\circ} \mathrm{C}$, and the specific activity of immobilized PPL was 1.42-fold higher than that of the free enzyme. The SDS ligand on the nanoparticles' surface acted as a spacer between the nanoparticles and the enzymes, which resulted in a flexible enzyme structure form. CRL was also immobilized on functionalized superparamagnetic nanoparticles (poly(GMA)-grafted $\mathrm{Fe}_{3} \mathrm{O}_{4} / \mathrm{SiO}_{\mathrm{x}}$ ) by Lei et al. [64]. Poly-(glycidyl methacrylate) (GMA) was grafted onto the surface of $\mathrm{Fe}_{3} \mathrm{O}_{4} / \mathrm{SiO}_{\mathrm{x}}$ by radical polymerization. The diameter of the functionalized magnetic nanoparticles was $100 \mathrm{~nm}$ and showed higher saturation magnetization $(8.3 \mathrm{kA} / \mathrm{m})$. The immobilized CRL showed better $\mathrm{pH}$ resistance and thermal stability, and its residual activity remained at $83 \%$ of the initial activity after being reused six times. CRL was covalently bound to $\mathrm{Fe}_{3} \mathrm{O}_{4}$ magnetic nanoparticles $(12.7 \mathrm{~nm})$ using carbodiimide activation. The $\mathrm{Fe}_{3} \mathrm{O}_{4}$ magnetic nanoparticles-immobilized lipase showed 1.41-fold enhanced activity, 31-fold enhanced stability, and better tolerance to changes of solution $\mathrm{pH}$ compared to the free enzyme [65]. Thangaraj et al. [66] examined the effect of various $\mathrm{SiO}_{2}$ ratios for coating on $\mathrm{Fe}_{3} \mathrm{O}_{4}$ and further functionalization of $\mathrm{Fe}_{3} \mathrm{O}_{4} / \mathrm{SiO}_{2}$ magnetic nanoparticles using organosilane compounds (3-aminopropyltriethoxysilane (APTES) and 3-mercaptopropyltrimethoxysilane (MPTMS)) for lipase immobilization. When the $\mathrm{Fe}_{3} \mathrm{O}_{4}: \mathrm{SiO}_{2}$ ratio was 1:0.25, the immobilization efficiency was the highest. The immobilized lipase on functionalized $\mathrm{Fe}_{3} \mathrm{O}_{4} / \mathrm{SiO}_{2}$ magnetic nanoparticles using APTES showed the best catalytic activity. ATPES might help to improve the surface characterization of magnetic nanoparticles.

\subsection{Carbon Nanotubes-Based Lipase Immobilization}

Carbon nanotubes are promising materials for enzyme immobilization. Carbon nanotubes based on graphitic sheets have a unique structure that rolls into a cylindrical shape [71]. Carbon nanotubes, including single-walled nanotubes (SWNTs) and multi-walled carbon nanotubes (MWNTs), are used 
for enzyme immobilization (Table 1) [43,55-59]. Lee et al. [55] immobilized PCL onto SWNTs using two different solvent systems (buffer and ionic liquid). In the buffer solution, carbon nanotubes are basically insolube because of the van der Waals forces of SWNTs. The use of an ionic liquid increased the immobilization efficiency via providing a better dispersion of carbon nanotubes than buffer solution. MWNTs can load a large amount of enzyme [71]. Lipases were immobilized in carbon nanotube-silica composites in an anion-aqueous reaction system [56]. MWNTs were used as additives to prevent lipase inactivation during the sol-gel process. The activity of three types of lipases (Candida rugosa, Candida antarctia type B, and Thermomyces lanuginous) with 2.7\% (w/w) MWNT was enhanced 10-fold than the lipase immobilized without MWNT in a esterification reaction. The immobilized lipase with $2.7 \%$ MWNT retained $96 \%$ of the initial activity after five reuses, whereas the immobilized lipase without MWNT was completely deactivated under the same condition. C. rugosa lipase (CRL) was also attached to MWNTs [43,56-59]. CRL was immobilized on MWCT through physical adsorption, and a high retention of catalytic activity of up to $97 \%$ was observed. The immobilized CRL showed 2.2- and 14-fold increases in the initial rate of transesterification in hexane and water-immiscible ionic liquids (Bmim) (PF6), respectively [57]. Mohamad et al. [58] reported a simple adsorption method to immobilize CRL onto acid-functionalized MWNTs (F-MWNTs). The polar groups $\left(\mathrm{COO}^{-}\right)$were introduced to the MWNTs via stirring with an acid mixture containing $\mathrm{H}_{2} \mathrm{SO}_{4}$ and $\mathrm{HNO}_{3}$. The charged carboxyl moieties on the MWNTs' surfaces could be connected with other polar moieties $\mathrm{NH}_{2}$ and $\mathrm{OH}$ ) on the CRL. The immobilized CRL on acid F-MWNTs had improved structural integrity and mechanical strength. The activity and thermal stability of the immobilized CRL on MWNTs were twofold enhanced compared to those of the free enzyme.

\subsection{Electrospun Nanofibers-Based Lipase Immobilization}

Some nanoparticles and nanotubes can suffer from mass-transfer limitation and difficulty in recycling because of their good dispersion [72]. Electrospun nanofibers are promising carriers to overcome these issues [44,60-63]. Nanofiber membranes have a large surface area for enzyme loading and high porosity for efficient substrate diffusion. Lipases were attached to the surface of electrospun nanofibers as the carrier or entrapped in the nanofibers [52]. Nanofiber membranes with carboxyl groups were made from poly(acrylonitrile-co-maleic acid) (PANCMA) via an electrospinning process [59]. The immobilized CRL on this nanofiber membrane showed an enhanced enzyme loading (from 2.36 to $21.2 \mathrm{mg} / \mathrm{g}$ ) and increased activity (from 33.9 to $37.6 \%$ ) compared to those of the hollow-fiber membrane. The efficiency of the biocatalysis increased because the $K_{m}$ value of the immobilized lipase decreased. Huang et al. [61] reported the development of immobilized CRL on an electrospun cellulose nanofiber membrane via covalent binding. The nanofiber was made by electrospun cellulose acetate. Then, it was oxidized using $\mathrm{NaIO}_{4}$ to produce aldehyde groups, which can be covalently bonded with enzyme molecules. The activity of immobilized CRL was $29.6 \mathrm{U} / \mathrm{g}$ under an optimal condition, and the thermal stability was higher than that of free enzyme. Song et al. analyzed the activity of encapsulated Burkholderia cepacia lipase (BCL) in polycarprolacone (PCL) nanofibers [62]. The activities of a BCL-PCL nanofiber were evaluated using two reaction models: hydrolysis activity in aqueous media and transesterification activity in non-aqueous media. The specific hydrolysis activity was higher than the transesterification activity. The immobilized BCL maintained $50 \%$ of its initial activity up to the 10 th recycle in non-aqueous media.

\section{Biodiesel Production Using Nano-Immobilized Lipase}

Recently, enzyme immobilization using nanomaterials as carriers has been developed and used in biodiesel production (Table 2) [67,73-82]. The improvement of enzyme activity, stability, and reusability by employing nano-immobilized enzyme systems can reduce the cost of enzyme use. In the biodiesel production process, the immobilized lipases were disrupted by shear stress from the stirring in the batch reaction [45], indicating that reaction systems need to be developed for biodiesel production. Wang et al. [67] successfully developed a packed-bed reactor system using immobilized lipase on 
$\mathrm{Fe}_{3} \mathrm{O}_{4}$ nanoparticles. The biodiesel conversion was over $88 \%$ for $192 \mathrm{~h}$ using a four-packed-bed reactor. The four-packed-bed reactor exhibited higher conversion and stability than a single-packed-bed reactor. As a result, the four-packed-bed reactor has been proved to have a great potential in biodiesel production based on large-scale nanobiocatalytic systems.

Table 2. Summary of investigations on biodiesel production using nano-immobilized lipase. mMWNCT: magnetic multi-walled carbon nanotube.

\begin{tabular}{|c|c|c|c|c|c|}
\hline Strain & Carrier & Substrate & $\begin{array}{c}\text { Biodiesel } \\
\text { Coversion (\%) }\end{array}$ & $\begin{array}{c}\text { Reusability (Days } \\
\text { Or Cycles) }\end{array}$ & Refs. \\
\hline \multirow{3}{*}{ Pseudomonas cepacia } & $\mathrm{Fe}_{3} \mathrm{O}_{4}$ & Soybean oil & 88 & 10 days & [67] \\
\hline & \multirow{2}{*}{ PAN-nanofiber } & Rapeseed oil & 94 & 20 days & {$[73]$} \\
\hline & & Soybean oil & 90 & 10 cycles & [74] \\
\hline \multirow{3}{*}{$\begin{array}{l}\text { Thermomyces } \\
\text { lanuginosa }\end{array}$} & \multirow{2}{*}{ Amino- $\mathrm{Fe}_{3} \mathrm{O}_{4}$} & Soybean oil & 90 & 4 cycles & [75] \\
\hline & & Palm oil & 97 & 5 cycles & [76] \\
\hline & Epoxy-silica & Canola oil & 99 & 20 cycles & [82] \\
\hline \multirow{3}{*}{ Burkholderia sp. } & Amino- $\mathrm{Fe}_{3} \mathrm{O}_{4}-\mathrm{SiO}_{2}$ & Waste cooking oil & 91 & 3 cycles & [77] \\
\hline & \multirow{2}{*}{ Alkyl- $-\mathrm{Fe}_{3} \mathrm{O}_{4}-\mathrm{SiO}_{2}$} & Olive oil & 90 & 10 cycles & [80] \\
\hline & & Chlorella vulgaris & 90 & 2 cycles & {$[81]$} \\
\hline \multirow{2}{*}{ Rhizomucor miehei } & PAMAM-mMWCNT & Waste cooking oil & 94 & 10 cycles & [78] \\
\hline & Epoxy-silica & Canola oil & 95 & 7 cycles & [82] \\
\hline \multirow{2}{*}{ Candida antarctica } & Epoxy- $\mathrm{Fe}_{3} \mathrm{O}_{4}-\mathrm{SiO}_{2}$ & Waste cooking oil & 100 & 6 cycles & [79] \\
\hline & Epoxy-silica & Canola oil & 59 & 15 cycles & [82] \\
\hline
\end{tabular}

Raita et al. [76] studied biodiesel production from palm oil using immobilized Thermomyces lanuginosus lipase (TLL) on magnetic nanoparticles. The biodiesel production yield was $97.2 \%$ under optimal conditions (23.2 wt \% enzyme loading, 4.7:1 molar ratio of methanol to oil, and 3.4\% water content at $50{ }^{\circ} \mathrm{C}$ for $24 \mathrm{~h}$ ). The attached lipases on the magnetic nanoparticles retained over $80 \%$ activity after five recycles. Waste cooking oil was also converted to biodiesel via transesterification using nano-immobilized lipase [77-79]. Karimi et al. [77] immobilized BCL on superparamagnetic iron-oxide nanoparticles (SIONs) for biodiesel production. The conversion of waste cooking oil to biodiesel was $91 \%$ within $35 \mathrm{~h}$. Fan et al. [78] obtained a high biodiesel yield of $94 \%$ from waste cooking oil using immobilized Rhizomucor miehei lipase (RML). The RML was immobilized onto polyamidoamine (PAMAM) grafted with magnetic multi-walled carbon nanotubes (MWCNTs) (m-MWCN-PAMAM). The immobilized RML showed 27-fold higher esterification activity than free RML, and there was no decrease in activity during 10 recycles. These results showed a great potential for biodiesel production.

Tran et al. [80] developed alkyl-functionalized $\mathrm{Fe}_{3} \mathrm{O}_{4}-\mathrm{SiO}_{2}$ nanocomposites for lipase immobilization. The immobilization efficiency on alkyl-grafted $\mathrm{Fe}_{3} \mathrm{O}_{4}-\mathrm{SiO}_{2}$ was 1.3-fold higher than non-functionalized $\mathrm{Fe}_{3} \mathrm{O}_{4}-\mathrm{SiO}_{2}$. The immobilized lipase was used for biodiesel production. The biodiesel conversion was over $90 \%$ for $30 \mathrm{~h}$ in batch operation. Tran et al. [81] also developed a one-step extraction and transesterification process of biodiesel production from wet microalgae biomass using alkyl-grafted $\mathrm{Fe}_{3} \mathrm{O}_{4}-\mathrm{SiO}_{2}$-immobilized lipase. The biodiesel conversion was over $90 \%$ under optimal conditions. The transesterification of soybean oil was catalyzed by a lipase immobilized on a polyacrylonitrile (PAN) nanofiber [74]. The biodiesel conversion was $90 \%$. The immobilized lipase on the nanofibers maintained $91 \%$ of its initial activity for 10 cycles. All of these results represent that nanomaterials can be used as a good carrier for lipase immobilization and that nano-immobilized lipase has potential for commercial application in biodiesel production.

\section{Conclusions}

Recently, various nanomaterials have attracted much attention as carriers for enzyme immobilization. Nanomaterials as immobilization carriers have many advantages, such as their large surface areas compared to other materials for enzyme immobilization. Many researchers have effectively immobilized lipases on functionalized nanomaterials, and their applications appear promising. 
In particular, the application of nano-immobilized lipase in packed-bed reactors resulted in high enzyme loading, multiple reuses, and effective protection from enzyme denaturation in biodiesel production, showing the potential of nano-immobilization technology in the biofuel industry. Further investigation, especially for the scale-up of the biodiesel production process, using nano-immobilized lipase is necessary to implement these technologies on an industrial level. The integrated development of a high enzyme and nano-immobilization technique will play a key role in cost-effective biodiesel production.

Acknowledgments: This research was supported by the Basic Science Research Program (2017R1A2B4007648) and the C1 Gas Refinery Program (2015M3D3A1A01064882) through the National Research Foundation of Korea (NRF) funded by the Ministry of Science and ICT.

Author Contributions: Keon Hee Kim wrote the manuscript draft. Ok Kyung Lee prepared figures and tables and revised the manuscript. Eun Yeol Lee conceptualized, revised, and finalized the manuscript. All authors read and approved the final manuscript.

Conflicts of Interest: The authors declare no conflicts of interest.

\section{References}

1. Harun, R.; Danquah, M.K.; Forde, G.M. Microalgal biomass as a fermentationfeedstock for bioethanol production. J. Chem. Technol. Biotechnol. 2010, 85, 199-203.

2. Ho, S.H.; Chen, C.Y.; Lee, D.J.; Chang, J.S. Perspectives on microalgal $\mathrm{CO}_{2}$-emissionmitigation systems: A review. Biotechnol. Adv. 2011, 29, 189-198. [CrossRef] [PubMed]

3. Al-Zuhair, S. Production of biodiesel: Possibilities and challenges. Biofuels Bioprod. Biorefin. 2007, 1, 57-66. [CrossRef]

4. Calero, J.; Luna, D.; Sancho, E.D.; Luna, C.; Bautista, F.M.; Romero, A.A.; Posadillo, A.; Berbel, J.; Verdugo-Escamilla, C. An overview on glycerol-free processes for the production of renewable liquid biofuels, applicable in diesel engines. Renew. Sustain. Energy Rev. 2015, 42, 1437-1452. [CrossRef]

5. Abbaszaadeh, A.; Ghobadian, B.; Omidkhah, M.R.; Najafi, G. Current biodiesel production technologies: A comparative review. Energy Convers. Manag. 2012, 63, 138-148. [CrossRef]

6. Gharat, N.; Rathod, V.K. Ultrasound assisted enzyme catalyzed transesterification of waste cooking oil with dimethyl carbonate. Ultrason. Sonochem. 2013, 20, 900-905. [CrossRef] [PubMed]

7. Hama, S.; Kondo, A. Enzymatic biodiesel production: An overview of potential feedstocks and process development. Bioresour. Technol. 2013, 135, 386-395. [CrossRef] [PubMed]

8. Azócar, L.; Heipieper, H.J.; Navia, R. Biotechnological processes for biodiesel production using alternative oils. Appl. Microbiol. Biotechnol. 2010, 88, 621-636. [CrossRef] [PubMed]

9. Ahmad, A.L.; Yasin, N.M.; Derek, C.J.C.; Lim, J.K. Microalgae as a sustainable energy source for biodiesel production: A review. Renew. Sustain. Energy Rev. 2011, 15, 584-593. [CrossRef]

10. Lee, O.K.; Seong, D.H.; Lee, C.G.; Lee, E.Y. Sustainable production of liquid biofuels from renewable microalgae biomass. J. Ind. Eng. Chem. 2015, 29, 24-31. [CrossRef]

11. Gui, M.M.; Lee, K.T.; Bhatia, S. Feasibility of edible oil vs. non-edible oil vs. waste edible oil as biodiesel feedstock. Energy 2008, 33, 1646-1653. [CrossRef]

12. Amini, Z.; Ilham, Z.; Ong, H.C.; Mazaheri, H.; Chen, W.H. State of the art and prospective of lipase-catalyzed transesterification reaction for biodiesel production. Energy Convers. Manag. 2017, 141, 339-353. [CrossRef]

13. Tacias-Pascacio, V.G.; Virgen-Ortíz, J.J.; Jiménez-Pérez, M.; Yates, M.; Torrestiana-Sanchez, B.; Rosales-Quintero, A.; Fernandez-Lafuente, R. Evaluation of different lipase biocatalysts in the production of biodiesel from used cooking oil: Critical role of the immobilization carrier. Fuel 2017, 200, 1-10. [CrossRef]

14. Kim, K.H.; Lee, E.Y. Environmentally-benign dimethyl carbonate-mediated production of chemicals and biofuels from renewable bio-oil. Energies 2017, 10, 1790. [CrossRef]

15. Ansari, S.A.; Husain, Q. Potential applications of enzymes immobilized on/in nano materials: A review. Biotechnol. Adv. 2012, 30, 512-523. [CrossRef] [PubMed]

16. Ahmad, R.; Sardar, M. Enzyme immobilization: An overview on nanoparticles as immobilization matrix. Biochem. Anal. Biochem. 2015, 4. [CrossRef]

17. Ding, S.; Cargill, A.A.; Medintz, I.L.; Claussen, J.C. Increasing the activity of immobilized enzymes with nanoparticle conjugation. Curr. Opin. Biotechnol. 2015, 34, 242-250. [CrossRef] [PubMed] 
18. Hwang, E.T.; Gu, M.B. Enzyme stabilization by nano/microsized hybrid materials. Eng. Life Sci. 2013, 13, 49-61. [CrossRef]

19. Gupta, M.N.; Kaloti, M.; Kapoor, M.; Solanki, K. Nanomaterials as matrices for enzyme immobilization. Artif. Cells Blood Substit. Immobil. Biotechnol. 2011, 39, 98-109. [CrossRef] [PubMed]

20. Sheldon, R.A. Cross-linked enzyme aggregates (CLEAs): Stable and recyclable biocatalysts. Biochem. Soc. Trans. 2007, 35, 1583-1587. [CrossRef] [PubMed]

21. Lopez-Serrano, P.; Cao, L.; Van Rantwijk, F.; Sheldon, R.A. Cross-linked enzyme aggregates with enhanced activity: Application to lipases. Biotechnol. Lett. 2002, 24, 1379-1383. [CrossRef]

22. Eş, I.; Vieira, J.D.G.; Amaral, A.C. Principles, techniques, and applications of biocatalyst immobilization for industrial application. Appl. Microbiol. Biotechnol. 2015, 99, 2065-2082. [CrossRef] [PubMed]

23. Tang, H.; Chen, J.; Yao, S.; Nie, L.; Deng, G.; Kuang, Y. Amperometric glucose biosensor based on adsorption of glucose oxidase at platinum nanoparticle-modified carbon nanotube electrode. Anal. Biochem. 2004, 331, 89-97. [CrossRef]

24. Kim, H.; Lee, I.; Kwon, Y.; Kim, B.C.; Ha, S.; Lee, J.H.; Kim, J. Immobilization of glucose oxidase into polyanilinenanofiber matrix for biofuel cell applications. Biosens. Bioelectron. 2011, 26, 3908-3913. [CrossRef] [PubMed]

25. Kim, Y.H.; Lee, I.; Choi, S.H.; Lee, O.K.; Kim, J.; Lee, E.Y. Nanoimmobilization of marine epoxide hydrolase of Mugil cephalus for repetitive enantioselective resolution of racemic styrene oxide in aqueous buffer. J. Nanosci. Nanotechnol. 2013, 13, 2266-2271. [CrossRef] [PubMed]

26. Hong, J.; Gong, P.; Xu, D.; Dong, L.; Yao, S. Stabilization of $\alpha$-chymotrypsin by covalent immobilization on amine-functionalized superparamagnetic nanogel. J. Biotechnol. 2007, 128, 597-605. [CrossRef] [PubMed]

27. Kim, B.C.; Nair, S.; Kim, J.; Kwak, J.H.; Grate, J.W.; Kim, S.H.; Gu, M.B. Preparation of biocatalytic nanofibres with high activity and stability via enzyme aggregate coating on polymer nanofibres. Nanotechnology 2005, 16, S382-S388. [CrossRef] [PubMed]

28. Fischback, M.B.; Youn, J.K.; Zhao, X.; Wang, P.; Park, H.G.; Chang, H.N.; Kim, J.; Ha, S. Miniature biofuel cells with improved stability under continuous operation. Electroanalysis 2006, 18, 2016-2022. [CrossRef]

29. Liu, H.; Hu, N. Study on direct electrochemistry of glucose oxidase stabilized by cross-linking and immobilized in silica nanoparticle films. Electroanalysis 2007, 19, 884-892. [CrossRef]

30. Kim, J.; Grate, J.W.; Wang, P. Nanobiocatalysis and its potential applications. Trends Biotechnol. 2008, 26, 639-646. [CrossRef] [PubMed]

31. Daubresse, C.; Grandfils, C.; Jerome, R.; Teyssie, P. Enzyme immobilization in nanoparticles produced by inverse microemulsion polymerization. J. Colloid Interface Sci. 1994, 168, 222-229. [CrossRef]

32. Reetz, M.T.; Zonta, A.; Vijayakrishnan, V.; Schimossek, K. Entrapment of lipases in hydrophobic magnetite-containing sol-gel materials: Magnetic separation of heterogeneous biocatalysts. J. Mol. Catal. A Chem. 1998, 134, 251-258. [CrossRef]

33. Yang, H.H.; Zhang, S.Q.; Chen, X.L.; Zhuang, Z.X.; Xu, J.G.; Wang, X.R. Magnetite-containing spherical silica nanoparticles for biocatalysis and bioseparations. Anal. Chem. 2004, 76, 1316-1321. [CrossRef] [PubMed]

34. Ma, D.I.N.G.; Li, M.; Patil, A.J.; Mann, S. Fabrication of protein/silica core-shell nanoparticles by microemulsion-based molecular wrapping. Adv. Mater. 2004, 16, 1838-1841. [CrossRef]

35. Naik, R.R.; Tomczak, M.M.; Luckarift, H.R.; Spain, J.C.; Stone, M.O. Entrapment of enzymes and nanoparticles using biomimetically synthesized silica. Chem. Commun. 2004, 15, 1684-1685. [CrossRef] [PubMed]

36. Min, K.; Yoo, Y.J. Recent progress in nanobiocatalysis for enzyme immobilization and its application. Biotechnol. Bioprocess Eng. 2014, 19, 553-567. [CrossRef]

37. Kim, J.; Grate, J.W. Single-enzyme nanoparticles armored by a nanometer-scale organic/inorganic network. Nano Lett. 2003, 3, 1219-1222. [CrossRef]

38. Yan, M.; Ge, J.; Liu, Z.; Ouyang, P. Encapsulation of single enzyme in nanogel with enhanced biocatalytic activity and stability. J. Am. Chem. Soc. 2006, 128, 11008-11009. [CrossRef] [PubMed]

39. Antczak, M.S.; Kubiak, A.; Antczak, T.; Bielecki, S. Enzymatic biodiesel synthesis-key factors affecting efficiency of the process. Renew. Energy 2009, 34, 1185-1194. [CrossRef]

40. Aarthy, M.; Saravanan, P.; Gowthaman, M.K.; Rose, C.; Kamini, N.R. Enzymatic transesterification for production of biodiesel using yeast lipases: An overview. Chem. Eng. Res. Des. 2014, 92, 1591-1601. [CrossRef] 
41. Guldhe, A.; Singh, B.; Mutanda, T.; Permaul, K.; Bux, F. Advances in synthesis of biodiesel via enzyme catalysis: Novel and sustainable approaches. Renew. Sustain. Energy Rev. 2015, 41, 1447-1464. [CrossRef]

42. Netto, C.G.; Andrade, L.H.; Toma, H.E. Enantioselective transesterification catalysis by Candida antarctica lipase immobilized on superparamagnetic nanoparticles. Tetrahedron Asymmetry 2009, 20, 2299-2304. [CrossRef]

43. Ji, P.; Tan, H.S.; Xu, X.; Feng, W. Lipase covalently attached to multi walled carbon nanotubes as an efficient catalyst in organic solvent. AIChE. J. 2010, 56, 3005-3011. [CrossRef]

44. Li, S.F.; Chen, J.P.; Wu, W.T. Electrospun polyacrylonitrile nanofibrous membranes for lipase immobilization. J. Mol. Catal. B Enzym. 2007, 47, 117-124. [CrossRef]

45. Verma, M.L.; Puri, M.; Barrow, C.J. Recent trends in nanomaterials immobilised enzymes for biofuel production. Crit. Rev. Biotechnol. 2016, 36, 108-119. [CrossRef] [PubMed]

46. Verma, M.L.; Barrow, C.J.; Puri, M. Nanobiotechnology as a novel paradigm for enzyme immobilisation and stabilisation with potential applications in biodiesel production. Appl. Microbiol. Biotechnol. 2013, 97, 23-39. [CrossRef] [PubMed]

47. Chen, Y.Z.; Ching, C.B.; Xu, R. Lipase immobilization on modified zirconia nanoparticles: Studies on the effects of modifiers. Process Biochem. 2009, 44, 1245-1251. [CrossRef]

48. Kim, M.I.; Ham, H.O.; Oh, S.D.; Park, H.G.; Chang, H.N.; Choi, S.H. Immobilization of Mucor javanicus lipase on effectively functionalized silica nanoparticles. J. Mol. Catal. B Enzym. 2006, 39, 62-68. [CrossRef]

49. Miletić, N.; Abetz, V.; Ebert, K.; Loos, K. Immobilization of Candida antarctica lipase B on polystyrene nanoparticles. Macromol. Rapid Commun. 2010, 31, 71-74. [CrossRef] [PubMed]

50. Wu, Y.; Wang, Y.; Luo, G.; Dai, Y. Effect of solvents and precipitanton the properties of chitosan nanoparticles in a water-in-oil microemulsion and its lipase immobilisation performance. Bioresour. Technol. 2010, 101, 841-844. [CrossRef] [PubMed]

51. Chronopoulou, L.; Kamel, G.; Sparago, C.; Bordi, F.; Lupi, S.; Diociaiuti, M.; Palocci, C. Structure-activity relationships of Candida rugosa lipase immobilised on polylactic acid nanoparticles. Soft Matter 2011, 7, 2653-2662. [CrossRef]

52. Chen, Y.Z.; Yang, C.T.; Ching, C.B.; Xu, R. Immobilization of lipases on hydrophobilized zirconia nanoparticles: Highly enantioselective and reusable biocatalysts. Langmuir 2008, 24, 8877-8884. [CrossRef] [PubMed]

53. Dyal, A.; Loos, K.; Noto, M.; Chang, S.W.; Spagnoli, C.; Shafi, K.V.; Ulman, A.; Cowman, M.; Gross, R.A. Activity of Candida rugosa lipase immobilized on $\gamma-\mathrm{Fe}_{2} \mathrm{O}_{3}$ magnetic nanoparticles. J. Am. Chem. Soc. 2003, 125, 1684-1685. [CrossRef] [PubMed]

54. Lee, D.G.; Ponvel, K.M.; Kim, M.; Hwang, S.; Ahn, I.S.; Lee, C.H. Immobilization of lipase on hydrophobic nano-sized magnetite particles. J. Mol. Catal. B Enzym. 2009, 57, 62-66. [CrossRef]

55. Lee, H.K.; Lee, J.K.; Kim, M.J.; Lee, C.J. Immobilization of lipase on single walled carbon nanotubes in ionic liquid. Bull. Korean Chem. Soc. 2010, 31, 650-652. [CrossRef]

56. Lee, S.H.; Doan, T.T.N.; Won, K.; Ha, S.H.; Koo, Y.M. Immobilization of lipase within carbon nanotube-silica composites for non-aqueous reaction systems. J. Mol. Catal. B Enzym. 2010, 62, 169-172. [CrossRef]

57. Shah, S.; Solanki, K.; Gupta, M.N. Enhancement of lipase activityin non-aqueous media upon immobilisation on multi-walled carbon nanotubes. Chem. Cent. J. 2007, 1, 30. [CrossRef] [PubMed]

58. Mohamad, N.; Buang, N.A.; Mahat, N.A.; Jamalis, J.; Huyop, F.; Aboul-Enein, H.Y.; Wahab, R.A. Simple adsorption of Candida rugosa lipase onto multi-walled carbon nanotubes for sustainable production of the flavor ester geranyl propionate. J. Ind. Eng. Chem. 2015, 32, 99-108. [CrossRef]

59. Pavlidis, I.V.; Tsoufis, T.; Enotiadis, A.; Gournis, D.; Stamatis, H. Functionalized multi-wall carbon nanotubes for lipase immobilisation. Adv. Eng. Mater. 2010, 12, B179-B183. [CrossRef]

60. Ye, P.; Xu, Z.K.; Wu, J.; Innocent, C.; Seta, P. Nanofibrous membranes containing reactive groups: Electrospinning from poly(acrylonitrile-co-maleic acid) for lipase immobilization. Macromolecules 2009, 39, 1041-1045. [CrossRef]

61. Huang, X.J.; Chen, P.C.; Huang, F.; Ou, Y.; Chen, M.R.; Xu, Z.K. Immobilization of Candida rugosa lipase on electrospun cellulose nanofiber membrane. J. Mol. Catal. B Enzym. 2011, 70, 95-100. [CrossRef]

62. Song, J.; Kahveci, D.; Chen, M.; Guo, Z.; Xie, E.; Xu, X.; Besenbacher, F.; Dong, M. Enhanced catalytic activity of lipase encapsulated in PCL nanofibers. Langmuir 2012, 28, 6157-6162. [CrossRef] [PubMed]

63. Nakane, K.; Hotta, T.; Ogihara, T.; Ogata, N.; Yamaguchi, S.J. Synthesis of (Z)-3-Hexen-1-yl acetate by lipase immobilised in polyvinylalcohol nanofibers. J. Appl. Polym. Sci. 2007, 106, 863-867. [CrossRef] 
64. Lei, L.; Liu, X.; Li, Y.; Cui, Y.; Yang, Y.; Qin, G. Study on synthesis of poly (GMA)-grafted $\mathrm{Fe}_{3} \mathrm{O}_{4} / \mathrm{SiO}_{\mathrm{x}}$ magnetic nanoparticles using atom transfer radical polymerization and their application for lipase immobilization. Mater. Chem. Phys. 2011, 125, 866-871. [CrossRef]

65. Huang, S.H.; Liao, M.H.; Chen, D.H. Direct binding and characterizationof lipase onto magnetic nanoparticles. Biotechnol. Prog. 2003, 19, 1095-1100. [CrossRef] [PubMed]

66. Thangaraj, B.; Jia, Z.; Dai, L.; Liu, D.; Du, W. Effect of silica coating on $\mathrm{Fe}_{3} \mathrm{O}_{4}$ magnetic nanoparticles for lipase immobilization and their application for biodiesel production. Arab. J. Chem. 2016. [CrossRef]

67. Wang, X.; Liu, X.; Zhao, C.; Ding, Y.; Xu, P. Biodiesel production in packed-bed reactors using lipase-nanoparticle biocomposite. Bioresour. Technol. 2011, 102, 6352-6355. [CrossRef] [PubMed]

68. Marta, Z.; Dorota, C.; Tomasz, S.; Adam, S.; Katarzyna, W.; Joanna, S.; Halina, K.; Marszałł, M.P. Chitosan-collagen coated magnetic nanoparticles for lipase immobilization-New type of "enzyme friendly" polymer shell crosslinking with squaric acid. Catalysts 2017, 7, 26.

69. Vaghari, H.; Jafarizadeh-Malmiri, H.; Mohammadlou, M.; Berenjian, A.; Anarjan, N.; Jafari, N.; Nasiri, S. Application of magnetic nanoparticles in smart enzyme immobilization. Biotechnol. Lett. 2016, 38, 223-233. [CrossRef] [PubMed]

70. Lu, A.H.; Salabas, E.E.; Schüth, F. Magnetic nanoparticles: Synthesis, protection, functionalization, and application. Angew. Chem. Int. Ed. Engl. 2007, 46, 1222-1244. [CrossRef] [PubMed]

71. Yang, N.; Chen, X.; Ren, T.; Zhang, P.; Yang, D. Carbon nanotube based biosensors. Sens. Actuators B Chem. 2015, 207, 690-715. [CrossRef]

72. Wang, Z.G.; Wan, L.S.; Liu, Z.M.; Huang, X.J.; Xu, Z.K. Enzyme immobilization on electrospun polymer nanofibers: An overview. J. Mol. Catal. B Enzym. 2009, 56, 189-195. [CrossRef]

73. Sakai, S.; Liu, Y.; Yamaguchi, T.; Watanabe, R.; Kawabe, M.; Kawakami, K. Production of butyl-biodiesel using lipase physically-adsorbed onto electrospun polyacrylonitrile fibers. Bioresour. Technol. 2010, 101, 7344-7349. [CrossRef] [PubMed]

74. Li, S.F.; Fan, Y.H.; Hu, R.F.; Wu, W.T. Pseudomonas cepacia lipase immobilized onto the electrospun PAN nanofibrous membranes for biodiesel production from soybean oil. J. Mol. Catal. B Enzym. 2011, 72, 40-45. [CrossRef]

75. Xie, W.; $\mathrm{Ma}, \mathrm{N}$. Immobilized lipase on $\mathrm{Fe}_{3} \mathrm{O}_{4}$ nanoparticles as biocatalyst for biodiesel production. Energy Fuels 2009, 23, 1347-1353. [CrossRef]

76. Raita, M.; Arnthong, J.; Champreda, V.; Laosiripojana, N. Modification of magnetic nanoparticle lipase designs for biodiesel production from palm oil. Fuel Process. Technol. 2015, 134, 189-197. [CrossRef]

77. Karimi, M. Immobilization of lipase onto mesoporous magnetic nanoparticles for enzymatic synthesis of biodiesel. Biocatal. Agric. Biotechnol. 2016, 8, 182-188. [CrossRef]

78. Fan, Y.; Wu, G.; Su, F.; Li, K.; Xu, L.; Han, X.; Yan, Y. Lipase oriented-immobilized on dendrimer-coated magnetic multi-walled carbon nanotubes toward catalyzing biodiesel production from waste vegetable oil. Fuel 2016, 178, 172-178. [CrossRef]

79. Mehrasbi, M.R.; Mohammadi, J.; Peyda, M.; Mohammadi, M. Covalent immobilization of Candida antarctica lipase on core-shell magnetic nanoparticles for production of biodiesel from waste cooking oil. Renew. Energy 2017, 101, 593-602. [CrossRef]

80. Tran, D.T.; Chen, C.L.; Chang, J.S. Immobilization of Burkholderia sp. lipase on a ferric silica nanocomposite for biodiesel production. J. Biotechnol. 2012, 158, 112-119. [CrossRef] [PubMed]

81. Tran, D.T.; Chen, C.L.; Chang, J.S. Effect of solvents and oil content on direct transesterification of wet oil-bearing microalgal biomass of Chlorella vulgaris ESP-31 for biodiesel synthesis using immobilized lipase as the biocatalyst. Bioresour. Technol. 2013, 135, 213-221. [CrossRef] [PubMed]

82. Babaki, M.; Yousefi, M.; Habibi, Z.; Mohammadi, M.; Yousefi, P.; Mohammadi, J.; Brask, J. Enzymatic production of biodiesel using lipases immobilized on silica nanoparticles as highly reusable biocatalysts: Effect of water, t-butanol and blue silica gel contents. Renew. Energy 2016, 91, 196-206. [CrossRef]

(C) 2018 by the authors. Licensee MDPI, Basel, Switzerland. This article is an open access article distributed under the terms and conditions of the Creative Commons Attribution (CC BY) license (http:/ / creativecommons.org/licenses/by/4.0/). 